\title{
POLLUTANT ADVECTION AND DIFFUSION PROCESSES IN THE LAGOON OF FUNAFUTI ATOLL, TUVALU
}

\author{
Daisaku Sato, Tokyo Denki University, sato@g.dendai.ac.jp \\ HiromuneYokoki, Ibaraki University, hiromune.yokoki@vc.ibaraki.ac.jp
}

\section{INTRODUCTION}

Funafuti Atoll, where is located on the South Pacific (179 $11^{\prime} 50^{\prime \prime} \mathrm{E}, 8^{\circ} 31^{\prime} 16^{\prime \prime} \mathrm{S}$ ) is the capital atoll of Tuvalu. Most of residents live in Fongafale Island which is located in the eastern-side of the atoll. Lagoonal nearshore of Fongafale Island has a problem of nearshore pollutant caused by outflowing of untreated domestic wastewater. Sato et al.(2015) conducted the numerical simulation of the lagoonal flow field, and the particle advection simulation for estimating the pollutant transportation in the lagoon. However, the simulation was not included the diffusion process of pollutant. In this study, numerical simulation including advection-diffusion processes was conducted to understand the characteristics of the pollutant behavior in the lagoon of Funafuti Atoll.

\section{CALCULATION METHOD}

Three-dimensional Advection-diffusion equation was adopted to simulating the scalar value. The horizontal eddy viscosity coefficient was estimated by Smagorinsky model and the vertical eddy viscosity coefficient was calculated by Kowalik and Murty(1993). Time step of simulation was set by 60s. The flow field of every 10 minutes in 2010, which were simulated by Sato et al(2015) using the Princeton Ocean Model(POM ver4.7.1), were used in velocity component of equation. The pollutant source area was set in the lagoonal nearshore zone of Fongafale Island located in the eastern part of the atoll. As the boundary condition of pollutant outflow the cell's scalar value of the pollutant source area were set by 10 continuously.

\section{CHARACTERISTICS OF THE POLLUTANT TRANSPORTATION}

Monthly characteristics of pollutant behavior were considered by the simulated pollutant distribution in the lagoon. Figure 1 indicated that the simulated results of the surface pollutant transportation in the end of January, March, May and July. In the figure the shading of color shows the depth of pollutant and the black areas indicate the islands. From the figure it is indicated that the pollutants were transported to the western part of the atoll. The pollutants distribute widely in the lagoon and change the transport direction seasonally. In January and March the pollutants were transported to northwestern-part of the atoll. On the other hand the pollutants transportation direction in May and July was southwestern-part of the atoll. Thus the simulated pollutant distribution indicated that the western-part of the atoll was influenced by the pollutant outflowing from the Fongafale Island through a year, however, the pollutant transportation was different by season.

Pollutant volume ratio in the divided lagoonal area were calculated to consider the characteristics of small regional differences. In the northwest part, the pollutant
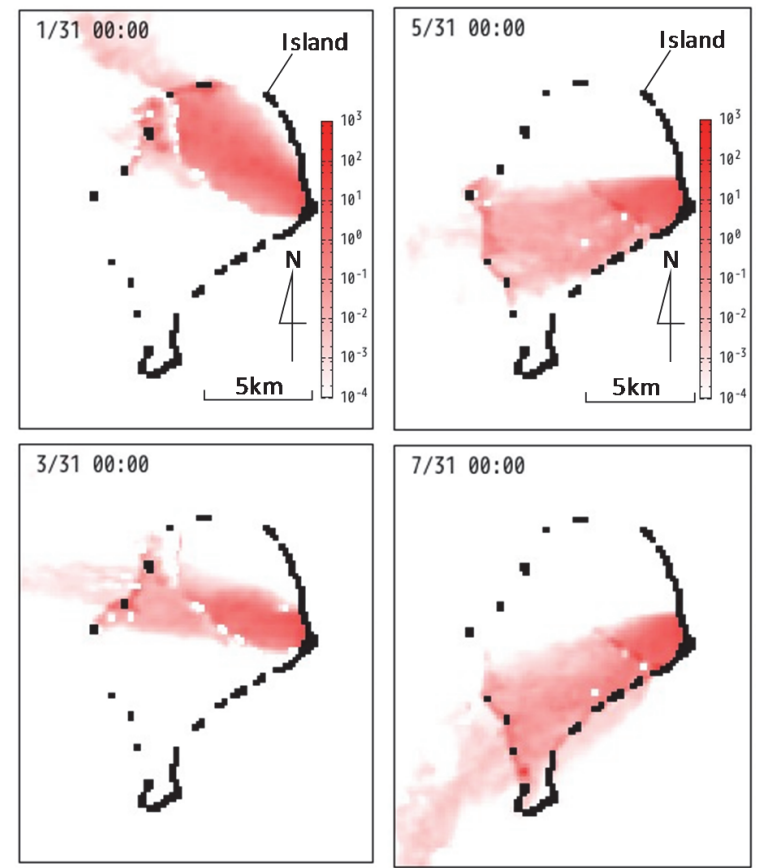

Figure 1 - Simulated results of pollutant advection and diffusion in Funafuti Atoll

volume ratio increased in January and February, reaching up to $40 \%$. The pollutant volume ratio in the western part of the lagoon increased in several month but the value of ratio was not so high compared with other areas. In the southwest part, the high ratio of pollutant volume which was $20 \sim 30 \%$, was calculated in July and August.

\section{CONCLUSION REMARKS}

Numerical simulations of pollutant transportation including advection and diffusion process were carried out for estimating the characteristics of the pollutant behavior in the lagoon of Funafuti Atoll. The simulated results of pollutant transportation indicated that the pollutants to outflow in the nearshore of Fongafale Island were transported to the western part of the atoll. In addition the final destination of the pollutants changed between northwestern and southwestern. Especially the northwestern part of the atoll had high pollutant volume ratio compared with other area of the lagoon.

\section{REFERENCES}

Sato, D., H. Yokoki and M. Arita (2015): Numerical Simulations of Lagoonal Flow Field and Pollutant Advection in Funafuti Atoll, Tuvalu, E-proceedings of the 36th IAHR World Congress, pp.1-8.

Kowalik, Z. and T. S. Murty (1993): Numerical modeling of ocean dynamics, Wold Scientific, pp.481. 